\title{
The reconstruction of Arab women role in media: a critical discourse analysis
}

\author{
M. Abdul Hamid ${ }^{1}\left[\right.$ Abdul Basid $^{1} \cdot$ Isma Nida Aulia ${ }^{1}$
}

Received: 11 July 2021 / Revised: 25 September 2021 / Accepted: 28 September 2021 / Published online: 20 October 2021

(c) The Author(s) 2021

\begin{abstract}
Arab women and the patriarchal culture are two things that cannot be separated. The influence of globalization and the rate of information and the Arab Spring revolution have such a profound impact on the identity of Arab women. The issue of discrimination and emancipation as a manifestation of the effort to re-actualize the identity of Arab women is widely reported in the media that we can see its progress day by day. This study shows how the media represents the identity of Arab women in Midan Al-Jazeera, Al-Ittihad, and mawdoo3 which contain problems in the social life of Arab women. As for the social reality of Arab society, women are positioned as individuals who can begin to actualize themselves. The data were analyzed by combining the concept of critical discourse analysis approach by Norman Fairclough and Teun A. Van Dijk who divided the analysis into three dimensions: text (micro), practical discourse (meso), and sociocultural (macro). The results show that the articles in Arab Media represent the re-actualization of Arab female identity using a specific discursive strategy in each of the articles. Through the texts in the article, Arab women are represented as free individuals, regardless of the role of wife and mother, and to have an active contribution to the social and autonomous sphere. It is under the conservative Arab government agenda toward a more moderate country in the twenty-first century.
\end{abstract}

Keywords Arab women $\cdot$ Critical discourse analysis $\cdot$ Identity $\cdot$ Media

\section{Introduction}

Nawal El Saadawi in her book expressed her awareness that Arab women in the past were slaves and oppressed (Saadawi 2003). The oppression of the women is not about east or west, or Islam and other religions, but it was caused by a classic yet prevalent patriarchal system in human society (Saadawi 2011). In this day and age, women are in the process of restoring the myth of feminism. They begin to express their freedom blatantly, but unfortunately, they are not, or have not been able to enjoy the life they want like men (Beauvoir 2016).

M. Abdul Hamid

hamidabdul@uin-malang.ac.id

Abdul Basid

abdulbasid@bsa.uin-malang.ac.id

Isma Nida Aulia

nidaaisma@gmail.com

1 Universitas Islam Negeri Maulana Malik Ibrahim Malang, Jl. Gajayana 50, Malang 65145, Indonesia
The identity of Arab women which is developing day by day can be seen through (re)constructions of the reality by the media. As time goes by, nowadays Arab women have gained various recognitions and their role is no longer ruled out. As proof of this, the news reported by kompas.com, on September 24, 2017, that the Arabs, as the most conservative country in managing gender differences issues, have allowed women to enter soccer stadiums which previously only men were allowed. Reporting from detik.com on January 12, 2018, a women's car showroom has been officially opened in Saudi Arabia after previously being reported on the same media. Saudi Arabia has also revoked the ban on women to drive last September 27, 2017. Over the past 27 years, since November 6, 1990, Saudi women are celebrating a long-fought movement when 47 women drove in the streets of Riyadh, Saudi Arabia. Driving was, in fact, not made officially illegal for women until after November 6, 1990. "The ladies of November," as they are known today-mostly teachers, academics, doctors, professionals, social workers, and housewives-demonstrated for their right to drive on Tuesday afternoon (Jarbou 2018). This shows the steps taken by Saudi Arabia to change the life of the society in 
the general, both men and women and demonstrate a greater improvement on gender equality and human rights.

Issues of discrimination and emancipation of women are reported massively by media. Ranging from electronic media, print media to online media, they provide various views on this issue. Talk about women becomes important when dealing with the media. The media is not neutral without value. The media appears with various and diverse contents. Various views and representations given by the media to an issue are often considered as a truth. As one of the tools of power, media is expected to have gender awareness by showing gender-sensitive attitudes and commitments to place women's needs and priorities in the center of development planning and programs and not to discriminate in any way. However, discrimination and other adverse conditions that women receive today cannot be separated from the role of the media that was strongly representing women in a rather disadvantage manner. Violence and discrimination that haunt women are because of representation from media which is still detrimental to women. Most media reports about women as inferior (Subandy 1998). Geertsema argued that in era of increasing globalization, women are continued to be underrepresented and stereotyped in national, international, and global media (Geertsema 2009). The questions about media and feminism were attracting to scholars (Courtney et al. 2020; Mahadeen 2015; Mattoscio and MacDonald 2018; Mendes and Silva 2011).

The practice of discourse in the media has produced an unbalanced ideological power relations between the social class; men and women as majority and minority groups. The difference is represented in the position displayed. The analytical approach used is critical. Guba in Badara (Badara 2014) stated that a critical approach is an approach that focuses on dismantling the hidden aspects behind virtual reality to carry out critique and transformation of the social structure.

Badara revealed that critical discourse analysis sees language as an important factor, how language is used to see power imbalances in society. Language is not only analyzed in terms of linguistic features per se, but also in terms of context-related issues as well. The context in question is intended as a particular practice, including the practice of the power to marginalize certain individuals or groups (Badara 2014).

The relations of women, feminism and media have been explored in several studies, how women activists and feminist organizations produce, develop, and share resources online (Courtney et al. 2020; Gajjala et al. 2010; Geertsema 2009; Mahadeen 2015; Mattoscio and MacDonald 2018; Mustafa-Awad et al., 2021) and in particular research on Arab women, Arab Spring, and Media (Al-Rawi 2014; Dashti and Mesbah 2016; Debbagh 2012; Eltantawy 2013; Jackson 2018; Jarbou 2018; Kaye-Essien and Ismail 2020;
Newsom and Lengel 2012; Radsch and Khamis 2013; Rahbani 2010). These studies shed light on relationship between Arab Women and Media in global context.

Despite the focus on the Arab Women and Media in global context, the content of the media specifically what was written on the text was often neglected. This paper investigated how the identity of Arab women was represented on the Arab online Media. The articles were published by Midan Al-Jazeera, Al-Ittihad, and mawdoo3 as Arab online Media that has an ideology of presenting social problems from young journalist's point of view. This study specifically examined two research questions: (1) How is the discourse on the actualization of Arab women represented in texts? (2) How is the female subject positioned in the social reality of Arab society?.

\section{Literature review}

\subsection{Arab women's identity}

Looking to Arabia, or Mecca where Islam was born, we will find the live burial of girls in the pre-Islamic Arabian nation. In the period of Jahiliyyah (before Islam), the Arab community saw the women as inferior. The Arab Jahiliyyah accepted women with two different events. Most of them bury their daughters alive because they assume that they have buried all that is shameful that befalls them. Other powers are somewhat different, they take care of the child in a painful and humiliating way. Wives in the Arabian Jahiliyyah period were inherited like property. Al-Bukhari relates that if a man died, then his sons have full rights to his wife (Seif and Said 1988).

Based on the traces of civilization above, it is clear that patriarchal forces are occurring in almost all of the world. In the nineteenth century, women could not tolerate the unfair treatment directed at them for centuries. So in Europe and the USA, women build the movement of women's emancipation. This movement is an effort so that women can take part in educational institutions. The pioneers of this movement are Sophia Bryan, France Marry Buss, and Dorothea Beale in Europe and Lucy Stone in America. They all fight for women's human rights (Seif and Said 1988).

Nawaal El Saadawi, one of the Egyptian feminists stated that in Arabia, argued that patriarchal norms and values continue to run rampant in homes, on the streets, schools, mosques, and workplaces, even in the concepts and attitudes presented by radio shows, television, film, theater, newspapers, and magazines. This is the situation of most women in Arab countries. Saadawi stated that she as an Arab woman realized that women were still slaves, still oppressed, not because they were Arabs or members of Islamic society, but because of the consequences of the patriarchal class system 
that had dominated the world for thousands of years. Independence for women will never be achieved unless they are united in a political movement (Saadawi 2011).

Experiences and mistakes have led to the growing maturity of women and men who play an important role in progressive parties and social movements. They need for a theory of social transformation that connects thought and action, reason with feelings and emotions, and that can build a new, higher relationship between men and women in their struggle for a better world (Saadawi 2011).

The creation of a women's movement in an Arab country means that the Arab movement for democracy, progress, and socialism can make every woman reach a level where there is a real mass movement. Only the Arabs themselves can formulate the theories, ideas, and forms of struggle they need to free them from all forms of oppression. Only with their struggle can they create a new Arab woman, living with her originality, being able to choose which is purer and more valuable in cultural traditions, while assimilating the progress of science and modern thought (Saadawi 2011).

The reconstruction of classical history will reveal a lot of political and economic causes that are the cause of the oppression of the poor and women in society carried out in the name of morality and religion. There is a connection between politics, economics, religion, and morals, and it is not possible to separate from one another (Saadawi 2002).

The events of the Arab Spring empowered men and women activists to express their dissatisfaction with the social reality through internet and social media. As women's equality, Arab women made some online movements to challenge stereotypes and old customs. These online movements portrayed a new identity and character of women who speak up without fear of being targeted or harmed. Al-Rawi suggest that the events of the Arab Spring led to several reforms in the Arab world and facilitated the creation of feminist movements. Social media such as Facebook was used to promote this kind of online activism and create a collective secular identity for the members of these movements (Newsom and Lengel 2012). Sahar Khamis (Newsom and Lengel 2012) argues, "The prolific online and offline political activities of Arab women over the last several months have contributed a new chapter to the history of both Arab feminism and the region." Newsom and Lengel argue that Arab women's effort have been noticeable and globally recognized through social media when they fit within global and western narrative norms. Feminists have determined it is possible to build identities online, masked in patriarchal characteristics so as to access power that generates feminist ideals (Debbagh 2012). Now, technology has given them a window to the world, through which they can interact with many people outside family circle. This aspect driving the enhanced social role of women (Maestri and Profanter 2017).

\subsection{Critical discourse analysis}

Fairclough divides discourse analysis into three dimensions, namely text, discourse practice, and sociocultural practice. In Fairclough model, the text is analyzed linguistically by looking at vocabulary, semantics, and sentence. He also included coherence and cohesiveness, how the inter-data and between sentiments are combined to form understanding (Darma 2014). These three dimensions were also stated by Van Dijk (1997) that the task of discourse analysis to provide integrated descriptions of three dimensions of discourse: (a) language use; (b) the communication of beliefs (cognition); and (c) interaction in social situations.

All of these elements are analyzed to see three things such as: (a) ideational which refers to certain representations which want to be displayed in a text that generally carries certain ideological content. This analysis basically wants to see how something is displayed in text that can carry certain ideological content; (b) relations, refers to the analysis of how the relationship between journalists and readers is constructed, such as whether the text is conveyed informally or formally, openly or closed; (c) identity refers to the particular construction of the identity of journalists and readers, and how these personalities and identities are to be displayed and illustrated in the text. Van Dijk (1998) stated that the identity is a mental representation between a personal as a unique human being-personal experience and biography - and social as a member of group that has representations based on criteria, activities, goals, norms, values, position, and resources.

Both Fairclough and Van Dijk attempt to connect between text analysis in micro-level and larger social context, in this case sociocultural practice. In analysis phase, the three stages are carried out together. Text analysis aims to analyze language critically. Discourse practice mediates text with sociocultural practices. That is, the relationship between sociocultural and text is indirect and linked to discourse practice (Darma 2014). Sociocultural context does not only influence discourse, but also vice versa; discourse may typically also define or change such characteristics of culture (Van Dijk 1997).

According to Darma (2014) there are three stages of analysis:

1. Description, which is to describe the contents and analysis descriptively of the text. Here, the text is explained without relation to other aspects. The steps taken are as follows:

- Researchers read and identify the female lexicon in the text 
- Researchers read and identify sentences related to women's discourse in the text

- Researchers record matters relating to women's discourse in the text

- Researchers describe the text strategies used in the text based on the identification of linguistic features in the text

- Interpretation, namely interpreting the text associated with the practice of discourse carried out. Here, the text is not analyzed descriptively. The steps taken are as follows:

- Researchers search for information related to the text producer (author) through writing and profiles on online media pages.

- Researchers write the results of the first stage of the analysis and relate it to the text producer.

- Explanation, aims to find an explanation for the results of our interpretation in the second stage. That explanation can be obtained by trying to connect the production of the text to the sociocultural practices of a media. The steps taken are as follows:

- Researchers look for data relating to the sociocultural practices of Arab women through news, research and relevant books.

- Researchers elaborate on the results of previous analyzes with sociocultural practices to find the positioning, motives and representation of women in online media discourse.

\section{Method}

This study employs Norman Fairclough's critical discourse analysis approach that divides it into three dimensions, namely text, discourse practice, and sociocultural practice. In the Fairclough model, the text is analyzed linguistically, by looking at vocabulary, semantics and sentence. He also included coherence and cohesiveness, how the inter-data and between sentiments are combined to form understanding (Darma 2014). This theory attempts to connect between text analysis at the micro-level and the larger social context, in this case sociocultural practice. In the analysis phase, the three stages are carried out together. Text analysis aims to analyze language critically. Discourse practice mediates text with sociocultural practices. That is, the relationship between sociocultural and the text is indirect and connected with discourse practice (Darma 2014). In text analysis, Fairclough (2003) proposes three steps of text analysis, namely description, interpretation, and explanation. The framework is the basis for the analysis of the discourse of the actualization of the identity of Arab women in the articles written in Arab online Media.
Data collection methods were carried out by listening to the use of spoken and written language. This method has basic techniques in the form of tapping techniques. In an effort to obtain data, researchers tap language usage either orally or in writing. In subsequent practice, the tapping technique is followed by reading and note-taking techniques, because researchers in this case are dealing with written language (Mahsun 2005). Van Leeuwen in Badara (1987) describes a discourse analysis model in revealing and studying the process of marginalizing a person or group in discourse. In content analysis stage, he had two concerns, namely exclusion and inclusion. The first one consists of the elements such as passivation, nominalization, and the substitution of clauses. In contrast, inclusion consists of the elements such as differentiation, objectivation-abstraction, nomination-categorization, nomination-identification, determination-indetermination, assimilation-individualization, and association-dissociation.

The data analysis technique used refers to Fairclough's analysis framework which includes three dimensions or three stages of analysis, the description stage is used to analyze the text in terms of linguistic features, interpretation stage to analyze the text production process, and situational context situations that background and explanatory stages to analyze the relationship between text and sociocultural context (Fairclough 2003). On the other hand, Van Dijk (2001 in El-Falaky 2015) suggest that the domain of CDA he calls as "theoretical triangle." His triangle describes three levels of analysis, namely discourse, cognition, and society. First, discourse covers all the communicative events whether written or spoken. Secondly, cognition involves personal as well as social cognition, beliefs and goals and any other mental representation involved in discourse. Finally, society in the theoretical triangular includes the local microstructures, societal and political structures, groups, institutions, systems, and social relations and processes.

\section{Findings and discussion}

The reconstruction of Arab Women Role is represented by discourse strategies such as inclusion identification, categorization, abstraction, and nomination strategies that were used in the articles on "Midan Al-Jazeera" online. Another finding is positive definitions given to women actors because women are positioned as part of Arab society that has equal rights in all matters including the public sphere.

There are four Laila Ar-Rifa'ie articles eliciting the discourse on the re-actualization of Arab women's identity, namely: 


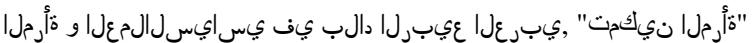

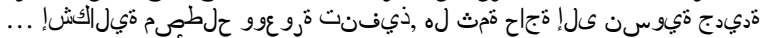

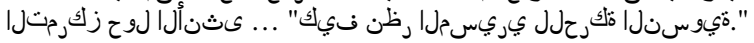 \\ Women and Political Action in the Countries of the Arab Spring, \\ "Women's Empowerment"... The Problem of Term and Difficult Implementation, Is There a Need for a New Feminism Centered on the Female... "How Elmessiri Viewed the Feminist Movement."}

The topics raised about women and the discourse on the re-actualization of Arab women identity were considered attractive, because in 2017 , the Arab countries as a conservative country made several changes in various aspects, one of which was in terms of empowering women. The manifestation of the re-actualization of the Arab woman identity is shown in the text as a free individual and regardless of her domestic role as wife and mother has the right to get a place in political contributions and get the right to education.

Discourse relating to "women has the right to politi-

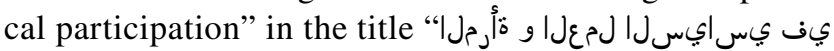
(ي.ب." The article as a whole speaks of women and political practices in Arab Spring countries. In the text, the author uses association inclusion discourse strategies which means the author mentions actors in the text as follows:

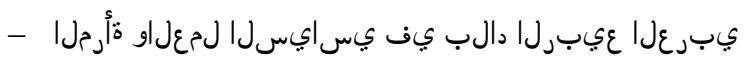

Another inclusion discourse strategy used in this text is identification discourse strategy as in the following quote:

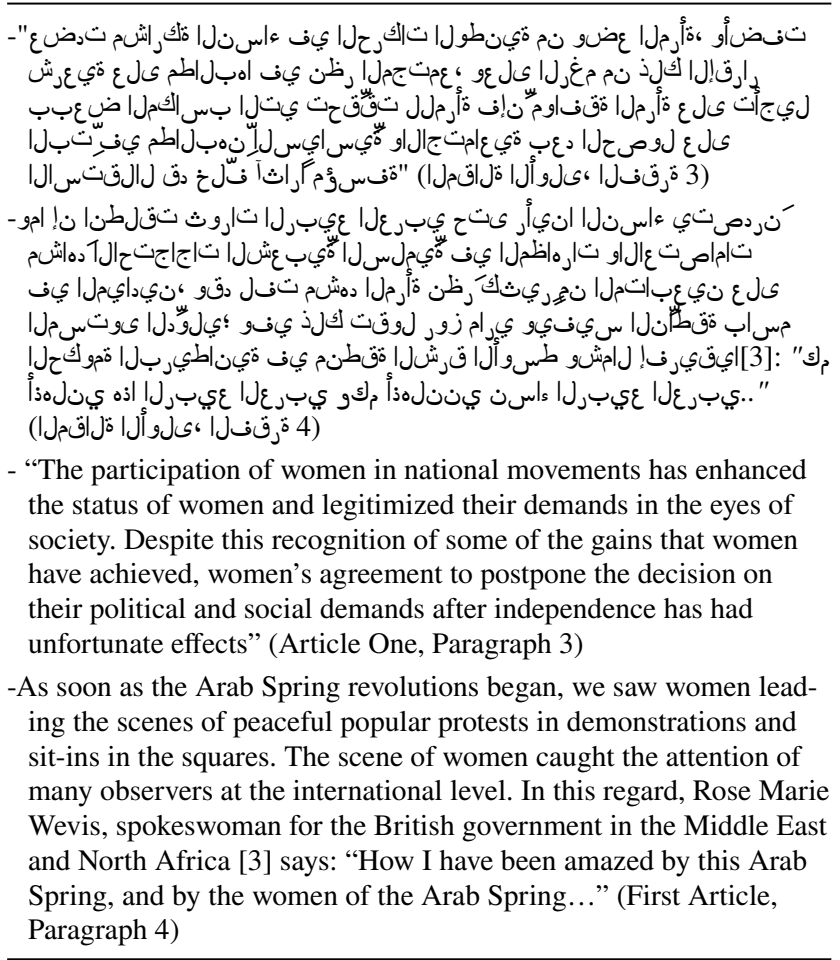

The quotation above explained about women's participation in the political sphere after the Arab revolution. After the Arab revolution, the Arabs, especially women, carried the topic of marginalization, oppression, and injustice and demanded freedom and empowerment especially in the political and social fields.

Another inclusion discourse strategy used in this text is the categorization inclusion discourse strategy as in the following quote:

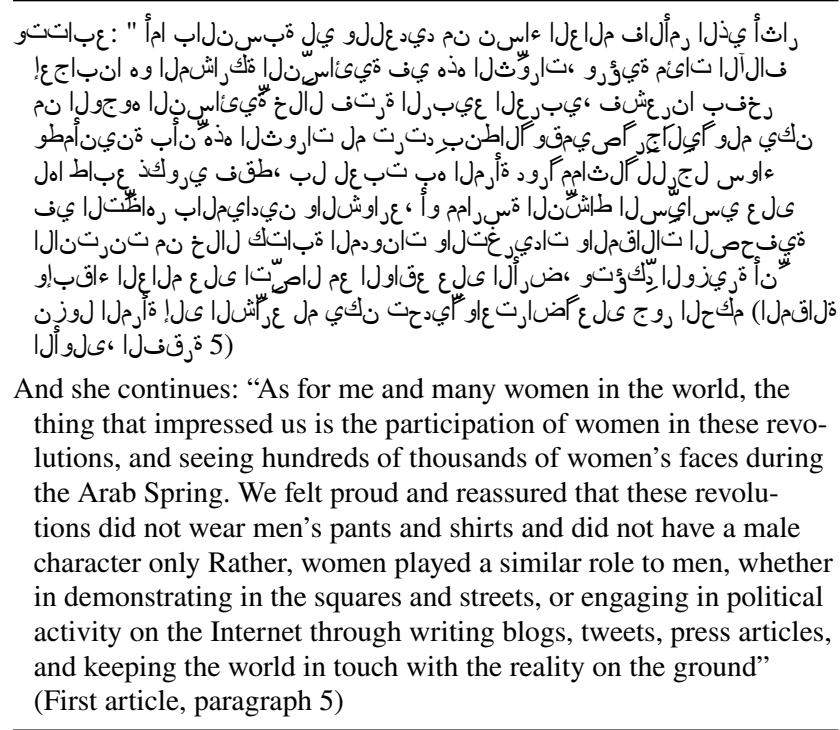

The discourse strategy used in the quotation above is a categorization. Women are explained to have the same nature and role as men so that women have the same rights as men. The text also demonstrated that the Arab Spring revolution was the result of something that was also fought for by women. But the success of this spring revolution did not become a spring for women in the political sphere who did not find their presence actively in several state institutions and state institutions. Women's rights outside the domestic sphere in fact still have to be fought for. So this prompted a group of elite Arab women to fight for these rights. This is in accordance with Riffat Hasan's opinion stating that women have rights and obligations whose portions are "equal" in quantity without having to think about the logical consequences that are present there of (Bidayah 2013). In addition, it was stated that the situation of women in this political community made them aware of the need to revolutionize the mental and thick patriarchal systems that are still held by the community. This also encourages them to emerge feminist models that are recognized in the political field.

The second article Laila Ar-Rifa'ie entitled "نيكت

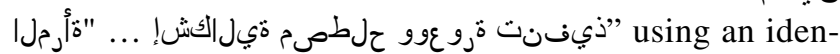
tification inclusion discourse strategy. As in the following quotations: 


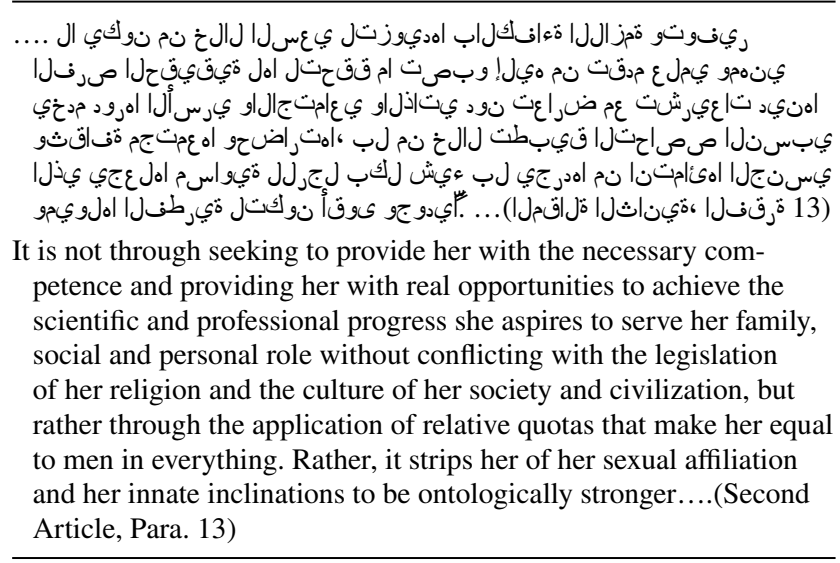

From the above quotation, it is stated that women's empowerment is an effort to overcome the problems of Arab women who have been in a marginal position. The empowerment of women is inseparable from the presence of Western factors which previously had practiced the feminism movement with the agenda of empowering women.

This women's empowerment departs from the understanding of equality promoted. Refuse the existence of biological discrimination which ends in the surrounding social discrimination. The implementation of women's empowerment is reflected in the nature of being juxtaposed with women in accordance with the discourse strategy used in the next quotation.

The inclusion discourse strategy contained in this text is categorization. As contained in the following quote:

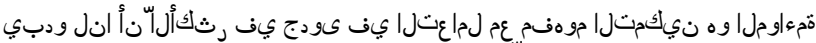

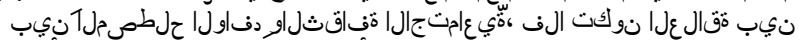

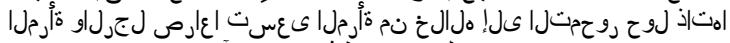

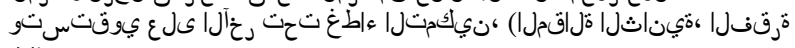

$$
\begin{aligned}
& \text { 44) }
\end{aligned}
$$

It seems to us that the most useful thing in dealing with the concept of empowerment is the harmonization between the new term and social culture, so that the relationship between women and men is not a struggle through which women seek to focus on themselves and empower the other under the cover of empowerment, (Second article, paragraph 44)

The excerpts of the above article can be a good marker of how women implement the women's empowerment agenda and how the text displays it. The discourse strategy used is the categorization strategy, namely the actors in this case women are displayed with certain characteristics. Women are characterized by all forms of participation in society and politics and women are positioned as responsible and dedicated actors in political activities. This is one form of reconstruction in traditional understanding held by women before, namely the role of women as wives and mothers. In the above quotations, it is clear that the author's bias toward women with our pronouns is clearly visible.

In the third article with the title " "öيدج the author of Laila Ar-Rifa'ie used Abstraction Inclusion to reconstruct the identity of Arab women. The discourse strategy is related to the depiction of an event or group of social actors using abstract portrayals. The word "ڤ" is" is a form of abstraction contained in the title. Note that the editor does not know the intended "ث̈," but to describe the reader's understanding of the word used without having to say it concretely. This understanding is achieved because of the context that has been present in the reader that Arabs as a conservative country must review the concept of feminism in social life.

The discourse strategy used by the author in the second article begins with an identification discourse strategy that explains the historical reality of the development of the Arab world feminism movement and how Islam influences the movement. This can be seen in the following quote:

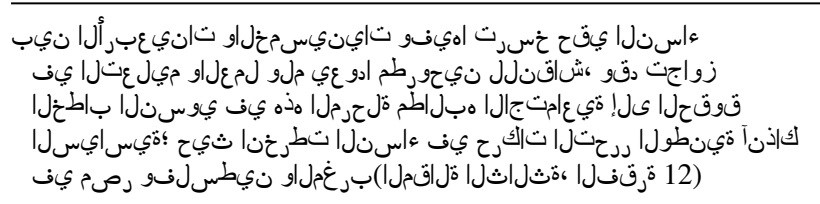

Between the forties and fifties, in which women's rights to education and work were firmly established and were no longer discussed. Feminist discourse at this stage exceeded its social demands to political rights, where women became involved in the national liberation movements at that time in Egypt, Palestine, and Morocco (third article, paragraph 12)

The strategy used in the next text is the categorization strategy it means how women as actors are syndicated and their relationship with the Arab feminism movement. With this movement, Arab women try to actualize women's identity by restructuring women's positions that take into account social and biological differences of view. This reconstruction discourse is based on women's awareness of women's rights that have not been fully fulfilled. This is articulated textually as follows:

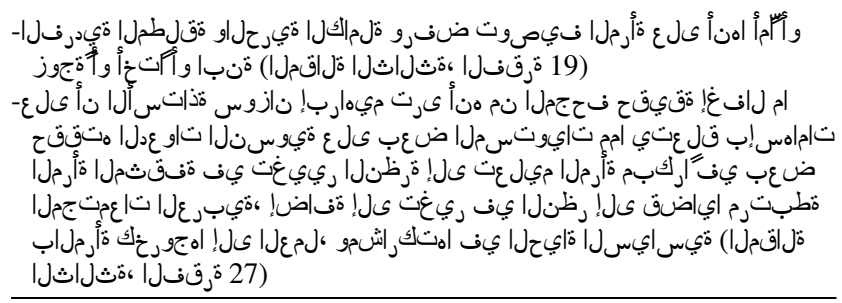


-Absolute individualism, complete freedom, and the refusal to characterize a woman as a mother, wife, sister, or daughter (third article, paragraph 19)

-However, Professor Suzan Ibrahim believes that it is unfair to neglect what feminist calls have achieved on some levels regarding the contributions of educated women in changing the perception of women's education at an early age in some Arab societies, in addition to a change in the perception of issues related to women such as their going out to work, and their participation on political life (third article, paragraph 27)

The discourse strategy used in the next quotation is the nomination discourse strategy, which is a discourse strategy. The text explains how Arabs actually respond to women's issues from a historical point of view and efforts to build justice for women as part of the progress of the Arab nation. The effort was realized with the new feminism movement that is based on the needs of the Arabs. A discourse that reviews the privacy space of Arab women on the basis of international feminism without removing the values of the Arab nation. This is reflected in the quotations of the following text:

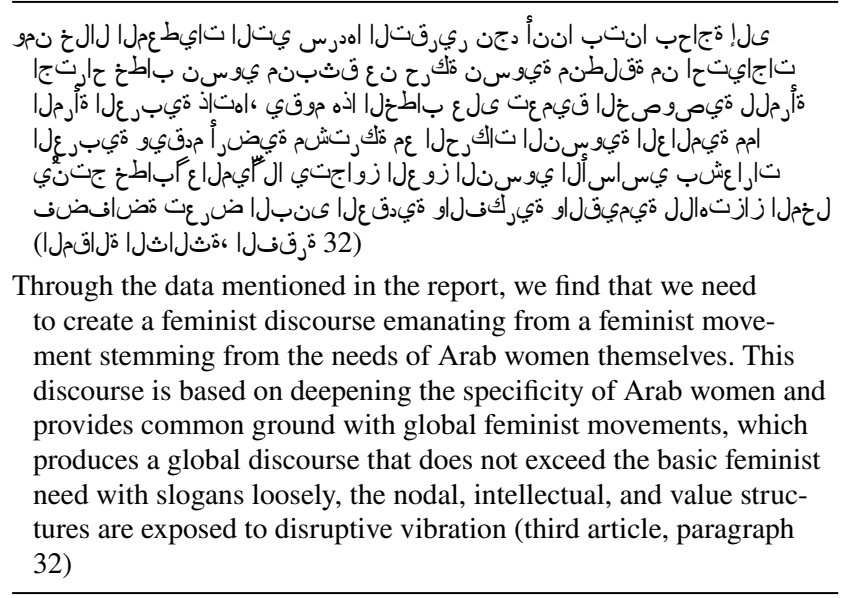

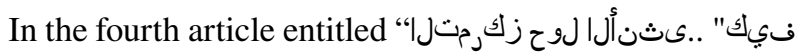
"Laila Ar-Rifa'ie reconstructs the identity of Arab women using Nomination Identification discourse strategy. The discourse strategy is related to the description of an event or group of social actors by giving clauses as explainers. A clause in the form of the

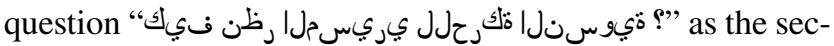
ond proposition is an explanation of the first proposition of

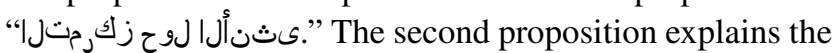
focus of the problems that arise on the agenda of " زكرحترك  the discourse on womanhood is an important component in the social life of Arab society.

The contents of the third article from Laila Ar-Rifa'ie begins with a description of women's awareness of their role in the domestic sphere which is often considered worthless because they are not paid. The revolution that was marked by the rapid development of social media had a negative impact on Arab women who felt inferior to what they did. Some texts related to this include the following:

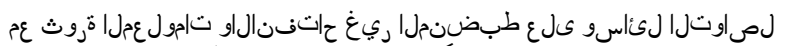

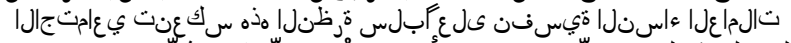

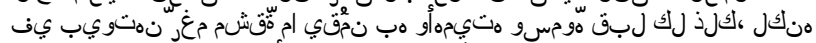

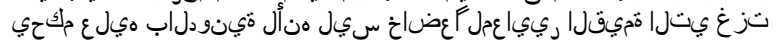

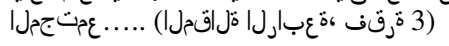

With the information revolution and uncontrolled openness on social media, this view is negatively reflected on the psyche of women working in their homes, despite the hardship, importance and loftyness of what they do above all, but it is judged inferior because it is not subject to the value standards that have invaded society..... (Fourth article, paragraph 3)

The social conditions that occur make Arab women movements actualize themselves in the midst of the flow of modernism and the deconstruction of thoughts that occur in society. One of these efforts is carried out by women through movements that reach out to the privacy of women in a container called feminism. Feminism is a movement that departs from the study of the position of traditional and modern women in the sphere of society. Driven by the concept that the history of human civilization is a place where women try to free themselves from male domination. One expression of women in reconditioning themselves is to break away from their qodrat identity as wife and mother. This is seen in the following text:

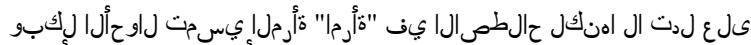

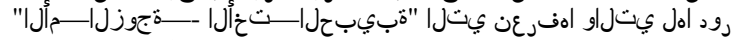

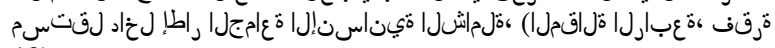

$$
\begin{aligned}
& \text { 10) }
\end{aligned}
$$

In any case, the woman becomes a "woman" in the terminology, but it does not denote the "mother-wife_—sister-beloved" that we know and who has an independent role within the framework of the universal human community (Fourth Article, paragraph 10)

In the quotation, the author uses an identification strategy with several clauses that explicitly have deconstructed the position of female actors in society through the meaning of the word "أرما:

Regarding this, Bosnian President Ali Izetbegovic responded that this was the beginning of renewing the identity of women by releasing their "motherly" identities whose positions were irreplaceable. The values of freedom that women call for can result in the collapse of family values and detachment from religious and moral ties.

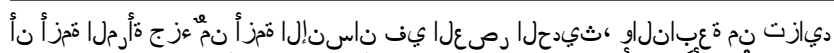

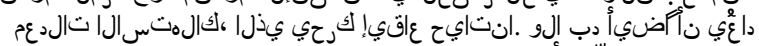

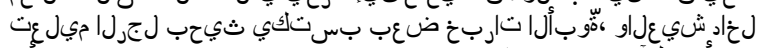

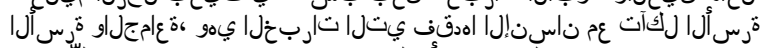

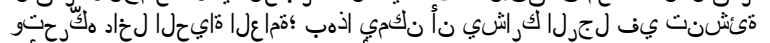

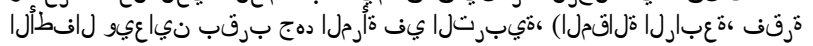
15)
} 
The crisis of women is part of the human crisis in the modern era, stemming from the increasing rates of consumption, which drives the rhythm of our lives. The man must also be re-educated so that he acquires some experiences of fatherhood, and living within the family and the community, which are the experiences that man has lost with the erosion of the family and his movement within public life; With this, the man can participate in the upbringing of children and closely examine the efforts of the woman in education (Fourth article, paragraph 15)

In the next text, it is stated that the women's liberation movement and the crisis they experienced were part of the crisis of modern life, one of which could be pursued by providing training in care for men and the experience of living in families and communities with the aim that men can synergize with women in terms of parenting so women can have an opportunity to get an education. This was also done by Huda Sha'rawi with Egyptian Feminist Union (EFU) who always tried to urge the Egyptian government so that women could continue their studies at a college (Sugiyono 2013). In this quote, women are positioned the same as men so there is no marginalization in the text.

In an article entitled "ركي له.ثقيمعو ةلقتسمو ةبيوق هأرمل| مذه لجرل| egy of inclusion, namely mentioning the main actors who are discussed and followed by a categorization nomination marked by the mention of women's characteristics as strong, independent and wise individuals. These characteristics are often assigned to men. This is one example of a re-actualization of the identity of Arab women, which at first was seen as a weak subject, but has now changed.

Apart from that the categorization nomination inclusion strategy is also found in the following quote:

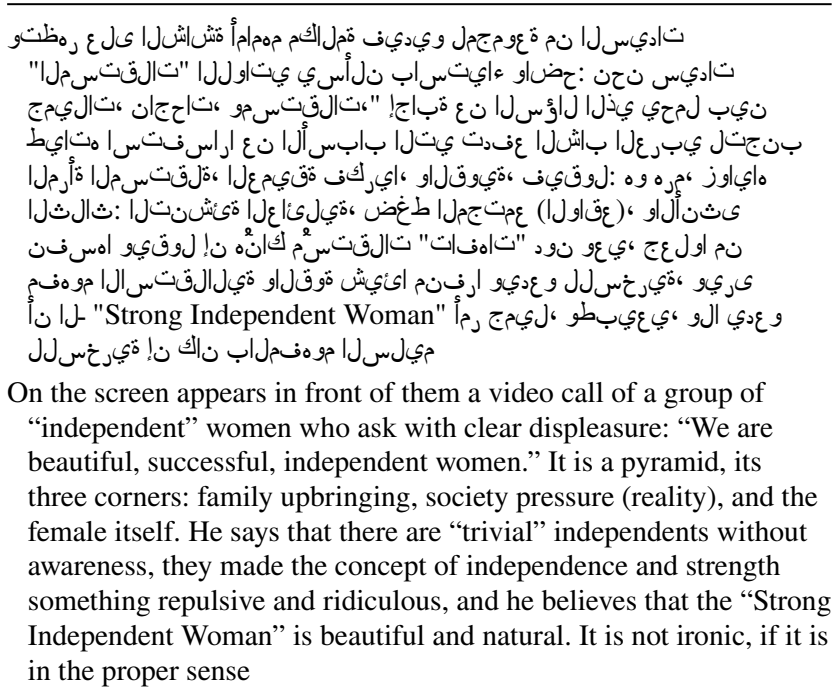

From the data above, there is a repetition of the word "تالقتسمل|" which means independent woman. Besides, the nature of independence is also associated with the

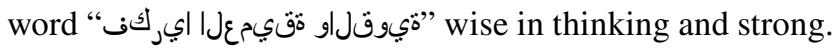

This shows that women in general and Arab women in particular have positioned them as strong individuals and are equal to men.

The use of a differentiation inclusion strategy is also seen in the following quote:

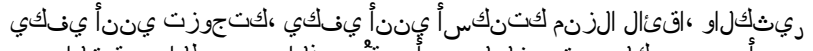

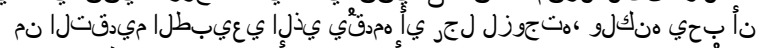

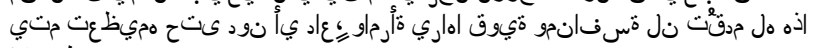

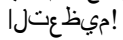

It suffices that I have married you that I have given you a decent house, and much of the natural introduction of any man to his wife, but he likes to be glorified even without any reason, and a woman whom he sees as strong and competitive will not give him that glorification!

In the quotation above, it appears that there is a strategy of differentiation discourse in which a man believes that his ability to provide for, provide a house and marry a woman makes a woman have to perfect her devotion to her husband. Meanwhile, women who have strong and competitive characteristics are judged by men to not obey men. Men as the hegemonic make the position of strong and independent women in this case represented not well.

In an article entitled "تاقو عم الب ئرل عو يفاقث روضح أر مل|فيتار امإل|" the author describes the challenges faced by Emirati women in the scientific and cultural fields (literature). During this period Arab women have shown active contributions to writing in a wide variety of fields. However, this is accompanied by the challenge of limited laws and regulations governing the production process in the scientific and literary fields. However, this is not too much of a barrier due to the lack of discrimination between men and women, support from the government and objective assessments. Although there was a minority who disagreed with the new role of women at this time, this could be stopped by the scholarship and achievements produced by Arab female scholars.

The dominant discourse strategy used in this article is inclusion, namely mentioning the main actor in the sentence, which in this case is an Arab woman. In addition, the strategy used is association, where the main actor is linked with the group. As contained in the following quotes:

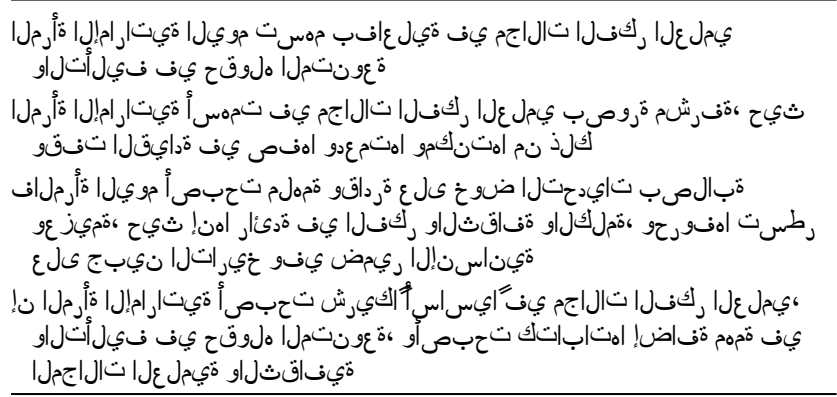


Emirati women today actively contribute to the fields of scientific

thought and authorship in its various fields

Emirati women have contributed in the fields of scientific thought in an honorable way, as the leadership stood by their side, supported them and enabled them to do so

Women today have become inspired and able to face challenges with firmness and determination, as they are pioneers in thought, culture and word, and their letters are written on the forehead of history and the conscience of humanity

Emirati women have become an essential partner in the fields of scientific thought and authorship in its various fields, and their writings have become an important addition in the scientific and cultural fields

In some of the quotes above, it is found that actors in this case Arab female thinkers are associated or linked to other

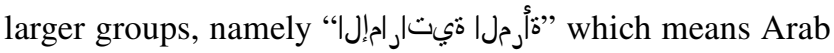
women in general. This shows that all Arab women generally have the same opportunity in terms of knowledge. Women thinkers in the United Arab Emirates have believed that they are able to face the challenges and pressures that occur and become the pioneers of thinking for the advancement of civilization. Their presence has been taken into account because of their intellectual value and responsibility. The challenges and obstacles that will be faced will not become obstacles but instead become new beginnings for learning.

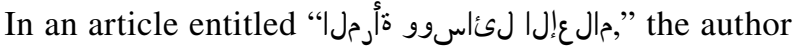
describes two topics, namely about women and their relation to information media. Today, the media is a means for empowering women in various fields. It is hoped that the media will be able to change people's views and behavior regarding the negative image of women. Even so, not all media are able to position women as partners in the development of civilization, this is indicated by the small number of women who are directly involved as mass media correspondents.

The reasons for the limited issues of women in the media include the lack of awareness of the roles, rights, problems and status of women in society. One way to overcome this is with government support in creating public discussion spaces that can be accessed by women, giving access to women to network on a wider scale and create programs aimed at enhancing the image of women in the media.

From the analyzed text discourse, the actors in the text are represented in three forms, namely differentiation, determination, and association.

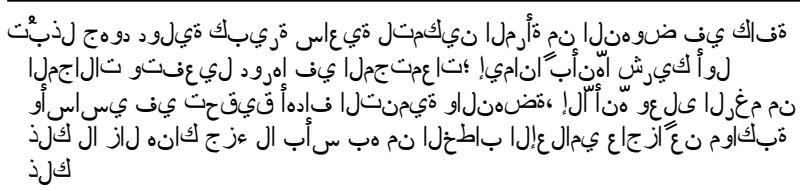

Great international efforts are being made to empower women to advance in all fields and activate their role in societies. Believing that it is a first and essential partner in achieving the goals of development and renaissance, but despite that, there is still a good part of the media discourse that is unable to keep pace with that

In the quote above there is differentiation, in this case, the hegemonic actor is the government that has sought to empower women in the field of cornering media actors as parties who do not balance it with positive news of female actors and still limiting women by presenting negative stereotypes that do not take into account the great potential that women have.

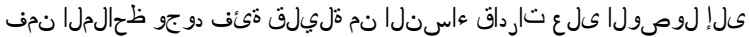

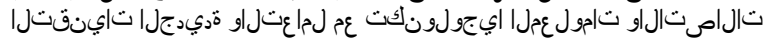

It is noticeable that there is a small group of women who are able to access new technologies and deal with information and communication technology
}

The strategy used in the quote above is determination, namely the abstraction or vagueness in representing female actors as a small group who are able to access new technology and deal with information and communication technology. This is probably because the author does not have sufficient evidence to write so it is safer to write with a small group who also indirectly asks the government to prepare and support programs that allow women to access resources related to new communication technologies.

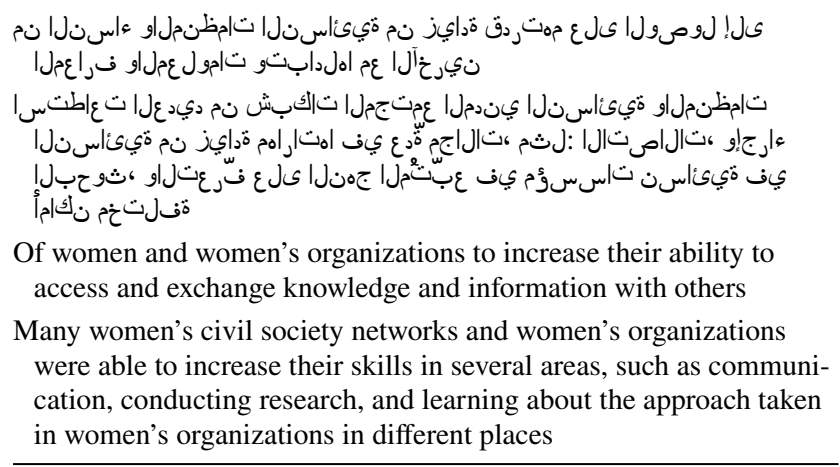

The strategy used in the quote above is association, namely Arab female actors, in this case represented by groups, namely the use of the word "عاس "

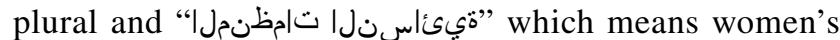
organization. This suggests that women are entirely to improve their ability to access knowledge and information and exchange with others, and to spread their ideas widely and quickly.

In this stage, micro-analysis or interpretation is done to find out the background of the appearance of the text, for whom the text is produced, the position of the text writer and the reader, and find certain ideological values contained in the text. 
In the first article written in January, Laila Ar-Rifa'ie raised the theme of the role of women in the political sphere after the Arab Spring revolutionary event. In the second article written in February, Laila Ar-Rifa'ie raised the theme of women's empowerment and its implementation in society. The third article written in April spoke of the discourse of deconstruction of feminism in Arabia. The fourth article written in July is about the problem of feminism from AlMassiri's point of view.

Based on the researchers interpretation of the background of the production of texts produced by this author is influenced by a patriarchal culture that is still firmly rooted in conservative Arab society. The revolutionary events of Arab Spring become a springboard for Arab women to actualize themselves and reconstructing their image or identity in the public domain so that women fight for equality through emancipation or feminism. So that in the text the dominant author places women as subjects not objects.

The position of the text writer in the depiction of social reality has a role as a subject / actor. This is because the writer is a woman who works as a journalist and comes from Syria which means it is very close to the reality of Arab women so it is very clear that the ideas presented in her writings tend to voice the fate of women toward a better one.

In some texts, the author uses the pronoun "us" which shows the communication between the writer and the female reader. The existence of this alignment was born from the understanding that occurred between the author and the intended audience. As for the ideology contained in the text is the ideology of feminism, which voices gender equality regarding the role of women in the public sphere.

Laila Ar-Rifa'ie, when referring to her background as a journalist in the social field, is closer to the lives of Arab women. In addition to discussing the actualization of Arab women, Laila wrote about the lives of Arab women in war zones such as Syria. Laila's writings strengthen her identity as part of a female journalist who brings the ideology of feminism in her writings.

Based on the results of the analysis of the description stage, it appears that the editorial of Midan Al-Jazeera in positioning women in superior position and generally use inclusion discourse identification, categorization, abstraction, and nomination strategies. In connection with this research, the definition given to women actors is a positive definition because women are positioned as part of Arab society that has equal rights in all matters including the public sphere. For example, women who contribute to the political realm, the appearance of different Arab women figures who dare to bring change, the identification of women who are built with scientific development, intellectual readiness and better education. This was done in an effort to make women able to answer the broader domain.
Globalization development and the flow of media that cannot be stopped, made women and scholars fight against patriarchal hegemony. The resistance is carried out by deconstructing ideology so that the ideology of feminism is born which voices gender equality.

The agenda motivates women to contribute more than the domestic domain (home and family). Women as women are defined as individuals who are free to actualize themselves in the public domain.

The efforts of feminists in actualizing women's identities are evidenced in various women's communities both nationally and internationally. Reporting from Midan.com, that in 1945, Jordan made unity of Jordanian women to handle all forms of female discrimination. In 1953, the Bahrain Women's Club was founded with a group of upper class women. A popular democratic organization representing Palestinian women was founded in 1965. In 1975, the United Arab Emirates formed a General Women's Union which supervised the league of Arab countries which had been assisted by the West. These organizations basically have the same outline that they exist to fight for women's equality in political, social and economic terms. In the course of the struggle, women get challenges and obstacles from within and from outside.

According to Ghozali (2011), among the causes of women's problems in classical politics in the Arab world are: Patrilineal Culture, conservative interpretation of religion, historical factors, women's education, fear in the face of controversy, family dimensions and experience factors.

The Arab Spring is a phenomenon that turns the autocracy system of the Arab world toward a democratic system. Although the process toward democracy is not easy and requires a long time, in this phase, people can voice all their demands, women's recognition of their rights, law and constitution as a country, shows that even though it is still far away, there is a system that is trying to be built (Yasmine 2015).

Reported from www.theguardian.com, Faizah Sulimani (29), a protest leader in Yemen, said that their demands are somehow similar to men, starting with freedom, equal citizenship and giving women a greater role in society. She said, "Women smell freedom at Change Square where they feel more welcomed than ever before. Their fellow (male) freedom fighters are showing unconventional acceptance to their participation and they are actually for the first time letting women be, and say, what they really want."

The Monitor's view stated that their involvement starts with showing women that granting their rights is good for their economic freedom, self-worth and safety. Many women privately endorse greater freedoms, but hesitate to lobby publicly for them. They fear they may bring shame on their families. 
The Arab women participation in the movement of Arab Spring has painted a new picture of them, they are not just a housewife, and not just a wife, or a mother, but a partner in the present and the future. They are rebellious and strongly demanding the rights of everyone, offering sacrifices, facing death in order to liberate the Arab world (Rabadi 2014).

One way to fight for their rights is not only by going to the field, but also by actively contributing in the world of information and media. Laila Ar-Rifa'ie was one of the young Syrian journalists who fought for women's rights through writing among other well-known Arab feminists such as Qasim Amin, Nawal El Saadawi, Zaynab Fawwaz Al-'Amili, Nazirah Zayn al-Din and others. In addition in the nineteenth century, there was a phenomenon of the proliferation of "Media Women" especially in Egypt and Lebanon, including Hind Nawfal's Al-Fatat (November 1892), Rosa Antoun's Majallat al-Sayyidat wa-1-Fatayat (1903), Mustafa 'Abd al Raziq's Al-Sufur (1915), Nabawiyyah Musa's Tarqiyat al-Fatat (1923) and Munirah Thabit's Al-Amal (1925) (Traboulsi 2003).

The sacrifice of these feminist fighters paid off, because the Crown Prince of Saudi Arabia, Mohammed bin Salman has made new breakthroughs in the Arab world with no exception in terms of women's development. Reported on www.cnnindonesia.com on October 25, 2017, at Riyadh's Future Investment Initiative forum, Prince Muhammad bin Salman said, "We promised to return the Saudis to true Islam, a moderate and open Islam for all religions and civilizations world."

This was realized with the issuance of driving licenses for women. In September 2017, the regulation also allowed women to go to cinemas, stadiums, showrooms, driving schools, got driving licenses and were permitted to work as tour guides. These are of a clear evident of the actualization of Arab women's identity in social life.

The Indonesian Ambassador to Saudi Arabia via CNN Indonesia, Agus Maftuh Abegebriel said: "This (fighting for women's freedom) is also proof that Saudi leaders have slowly taken their country toward a real moderation by giving women rights," this also confirms that the Saudis have entered into a major change in the twenty-first century.

\section{Conclusion}

The manifestation of the actualization of the identity of Arab women can be observed through the online media of Midan Al-Jazeera, one of which was written by a Syrian journalist Laila Ar-Rifa'ie. Through these articles, Arab women are shown as individuals who are free from their roles in the domestic realm as a mother and wife, those who have the right to get better education and have a place in the political sphere. In general, based on the analysis results of the description stage, the discourse strategy used appears that the editor of Midan Al-Jazeera positioned women in superior positions and generally using the discourse of inclusion identification, categorization, abstraction, and nomination strategies. In connection with this research, the definition given to women actors is a positive definition because women are positioned as part of Arab society that has equal rights in all matters including the public sphere. For example, women who contribute to the political realm, the appearance of Arab women figures who dare to bring different changes, the identification of women who are built with scientific development, intellectual readiness and better education. This was done in an effort to make women able to answer the broader domain.

The discourse is in line with what was revealed by Fatimah Mernissi regarding the participation of women historically not as historical objects but as historical subjects. Mernissi stressed that Islam affirms the idea of individuals as subjects who have freedom and awareness for sovereignty that will remain as long as they are alive. Based on various sources and historical works written by scientists, it was revealed that women have a very significant role in the formation of Islamic culture and civilization, not only limited in the political sphere, but also socially, culturally and others (Munfarida 2014). The statement was showed that she was completely envious to western women who can integrate and manage their past with modern era (Wahid 2000).

Open Access This article is licensed under a Creative Commons Attribution 4.0 International License, which permits use, sharing, adaptation, distribution and reproduction in any medium or format, as long as you give appropriate credit to the original author(s) and the source, provide a link to the Creative Commons licence, and indicate if changes were made. The images or other third party material in this article are included in the article's Creative Commons licence, unless indicated otherwise in a credit line to the material. If material is not included in the article's Creative Commons licence and your intended use is not permitted by statutory regulation or exceeds the permitted use, you will need to obtain permission directly from the copyright holder. To view a copy of this licence, visit http://creativecommons.org/licenses/by/4.0/.

\section{References}

Al-Rawi A (2014) Framing the online women's movements in the Arab world. Inf Commun Soc 17(9):1147-1161. https://doi.org/ 10.1080/1369118X.2014.889190

"Arab awakening: What About women" in https://www.csmonitor. com/Commentary/the-monitors-view/2011/0309/Arab-awake ning-What-about-women

Badara A (2014) Analisis wacana: Teori, metode, dan penerapannya pada wacana media. Prenada Media, Jakarta

Beauvoir SD (2016) Second Sex: Kehidupan Perempuan. Buku Seru, Jakarta 
Bidayah A (2013) Riffat Hassan dan Wacana Baru Penafsiran. Kalimah: Jurnal Studi Agama dan Pemikiran Islam 11(2):305-320

Courtney M, Breen M, McGing C, McMenamin I, O’Malley E, Rafter K (2020) Underrepresenting reality? Media coverage of women in politics and sport. Soc Sci Q 101(4):1282-1302. https://doi. org/10.1111/ssqu. 12826

Darma A (2014) Analisis Wacana Kritis dalam Multiperspektif. Bandung: Refika Aditma

Dashti AA, Mesbah H (2016) The perceptions of female media professionals in Kuwait about their job: an empowerment perspective. Fem Media Stud 16(2):276-292. https://doi.org/10.1080/14680 777.2015.1092459

Debbagh M (2012) Discourse analysis of the representations of women in Moroccan broadcast news. J N Afr Stud 17(4):653-670. https:// doi.org/10.1080/13629387.2012.685248

El-Falaky MS (2015) The representation of women in street songs: a critical discourse analysis of Egyptian Mahraganat. Adv Lang Lit Stud 6(5):1-8

Eltantawy N (2013) From veiling to blogging: WOMEN and media in the Middle East. Fem Med Stud 13(5):765-769. https://doi.org/ $10.1080 / 14680777.2013 .838356$

Fairclough N (2003) Language and power: Relasi Bahasa, Kekuasaan dan Ideologi. Boyan Publishing, Malang

Gajjala R, Zhang Y, Dako-Gyeke P (2010) Lexicons of women's empowerment online: appropriating the other. Fem Media Stud 10(1):69-86. https://doi.org/10.1080/14680770903457139

Geertsema M (2009) Women and news: making connections between the global and the local. Fem Media Stud 9(2):149-172. https:// doi.org/10.1080/14680770902814827

Ghozali S (2011) Pengaruh Pemikiran Feminisme terhadap PartisipasiPerempuan dalam Revolusi Mesir Tahun 2011. Fakultas Ilmu Sosial dan Politik. Universitas Muhammadiyah Yogyakarta. Yogyakarta, 2011

Jackson S (2018) Young feminists, feminism and digital media. Fem Psychol 28(1):32-49. https://doi.org/10.1177/0959353517716952

Jarbou R (2018) Know your enemy: the Saudi women's driving campaign from flyers and faxes to Youtube and hashtags. Fem Media Stud 18(2):321-325. https://doi.org/10.1080/14680777.2018. 1436902

Kaye-Essien CW, Ismail M (2020) Leadership, gender and the Arab media: a perception study of female journalists in Egypt. Fem Media Stud 20(1):119-134. https://doi.org/10.1080/14680777. 2018.1546212

Maestri E, Profanter A (n.d.) Arab women and the media in changing landscapes

Mahadeen E (2015) Media, state, and patriarchy. Fem Media Stud 15(5):763-778. https://doi.org/10.1080/14680777.2015.1028422

Mahsun (2005) Metode Penelitian Bahasa: Tahapan Strategi, Metode dan Tekniknya, Depok: PT. Raja Grafindo Persada. Muhammadiyah Yogyakarta

Mattoscio M, MacDonald MC (2018) Introduction: gender, migration, and the media. Fem Media Stud 18(6):1117-1120. https://doi.org/ $10.1080 / 14680777.2018 .1532142$

Mendes K, Silva K (2011) Introduction: gender, media, and activism. Fem Media Stud 11(4):499-500. https://doi.org/10.1080/14680 777.2011.615584
Munfarida E (2014) Analisis Wacana Kritis Dalam Perspektif Norman Fairclough. Jurnal Komunika 8(1)

Mustafa-Awad Z, Kirner-Ludwig M, Sawalha M (2021) "Arab women's Spring" revisited: media attitudes and public opinion in Germany. Fem Media Stud 21(2):189-210

Newsom VA, Lengel L (2012) Arab women, social media, and the Arab spring: applying the framework of digital reflexivity to analyze gender and online activism. J Int Women's Stud 13(5):31-45

Rabadi I (2014) Arab awakening: a feminist aesthetic prospective. Public Policy Admin Res 3(4):108-112

Radsch CC, Khamis S (2013) In their own voice: Technologically mediated empowerment and transformation among young Arab women. Fem Media Stud 13(5):881-890. https://doi.org/10.1080/ 14680777.2013 .838378

Rahbani LN (2010) Women in Arab media: present but not heard. Paper presented at a seminar at Stanford University, 16 February 2010

Saadawi N (2002) Perempuan, Agama dan Moralitas: Islam Feminis and Islam Revivalis. Erlangga, Jakarta

Saadawi N (2003) Wajah Telanjang Perempuan. Pustaka Pelajar, Yogyakarta

Saadawi N (2011) Perempuan Dalam Budaya Patriarki. Pustaka Pelajar, Yogyakarta

Seif A-H, Said A (1988) Citra Sebuah Identitas: Wanita Dalam Perjalanan Kesejarahan. Amarpress, Delhi

Subandy I (1998) Perempuan dan Media. Remaja Rosdakarya, Bandung

Sugiyono S(2013) Feminisme Di Dunia Muslim: Menguak Akar Perdebatan Antara Paham Konservatif Dan Reformis. Thaqafiyyat Journal 14(1)

Traboulsi F (2003) An intelligent man's guide to modern Arab feminism. Al-Raida 20(100):15-19

van Dijk TA (1997) Discourse as structure and process. Sage Publications Ltd, London

van Dijk TA (1998) Ideology: a multidiscipnary approach. Sage Publications Ltd, London

van Dijk, T. A. (2001). Multidisciplinary CDA: A plea for diversity. Meth Crit Discourse Stud 1:95-120

van Leeuwen T (1987) Generic strategies in press journalism. Aust Rev Appl Linguistics 10(2):199-220

Wahid HNDKK (2000) Membincang Feminisme: Diskursus Gender Perspektif Islam. Risalah Gusti, Surabaya

Women have emerged as key players in The Arab Spring. https://www. theguardian.com/world/2011/apr/22/women-arab-spring

Yasmine SE (2015) Arab Spring: Islam dalam gerakan sosial dan demokrasi Timur Tengah. Jurnal Masyarakat, Kebudayaan dan Politik 28(2):106-113

Publisher's Note Springer Nature remains neutral with regard to jurisdictional claims in published maps and institutional affiliations. 